\title{
Antidiabetic activity of Coccinia grandis (L.) Voigt: Bioactive constituents, mechanisms of action, and synergistic effects
}

\author{
I Made Wisnu Adhi Putra ${ }^{1,2}$ (D), Nanang Fakhrudin $3^{*}$ (D), Arief Nurrochmad ${ }^{4}$ D, Subagus Wahyuono ${ }^{3}$ \\ ${ }^{1}$ Doctoral Program of Faculty of Pharmacy, Universitas Gadjah Mada, Yogyakarta, Indonesia. \\ ${ }^{2}$ Department of Biology, University of Dhyana Pura, Badung, Bali, Indonesia. \\ ${ }^{3}$ Department of Pharmaceutical Biology, Faculty of Pharmacy, Universitas Gadjah Mada, Yogyakarta, Indonesia. \\ ${ }^{4}$ Department of Pharmacology and Clinical Pharmacy, Faculty of Pharmacy, Universitas Gadjah Mada, Yogyakarta, Indonesia.
}

\begin{tabular}{l}
\hline ARTICLE INFO \\
\hline Received on: 05/07/2021 \\
Accepted on: $17 / 09 / 2021$ \\
Available Online: 05/01/2022 \\
\\
\hline Key words: \\
Medicinal plant, ivy gourd, \\
diabetes mellitus, synergism.
\end{tabular}

\section{INTRODUCTION}

Diabetes mellitus is a chronic condition caused by abnormal glucose metabolism with hyperglycemia as its main feature. The world population suffering from diabetes (aged 20-79 years) was 463 million in 2019 (9.3\% of the world's total population). It is estimated that this number will rise to 578 million (10.2\%) in 2030 and 700 million (10.9\%) in 2045 (IDF, 2019). Diabetes is one of the top 10 causes of death worldwide. Approximately $90 \%$ of people with diabetes mellitus have the type

\footnotetext{
${ }^{*}$ Corresponding Author

Nanang Fakhrudin, Department of Pharmaceutical Biology, Faculty of Pharmacy, Universitas Gadjah Mada, Yogyakarta, Indonesia.

E-mail:nanangf@ugm.ac.id
}

two form, which is associated with population aging, obesity, and economic advancement, as well as urbanization, which is in turn associated with a more sedentary lifestyle and higher consumption of unhealthy foods (Basu et al., 2013; Hu, 2011; Viljoen and Sinclair, 2011).

Patients with diabetes are more likely than healthy people to develop severe and life-threatening complications, reduced quality of life, and undue family stress. Type 2 diabetes is usually treated with antidiabetic drugs, such as sulfonylureas, metformin, acarbose, thiazolidinediones, and meglitinides. However, the use of these drugs has disturbing adverse effects, such as nausea, vomiting, diarrhea, dilution anemia, weight gain, improved risk of heart failure and fractures, fever, hypoglycemia, and decreased appetite (Andersen and Christensen, 2016; GómezHuelgas et al., 2018; Kancherla et al., 2017; Loke et al., 2009; Seaquist et al., 2013). 
In view of the side effects of the abovementioned medications, the treatment of diabetes has shifted to the use of natural remedies. Herbal medicines are chosen for the treatment of diabetes because they are effective, easy to find, easy to process, free of side effects, and affordable (Arumugam et al., 2013). The phytochemicals contained in herbal medicines are responsible for their antidiabetic activity. It is known that herbal medicines contain phenolics, flavonoids, terpenoids, alkaloids, and other phytochemicals that exert antidiabetic-related effects, such as lowering blood glucose levels, lipid peroxidation, and insulin resistance, increasing insulin levels, inhibiting hexokinase enzyme activity, and acting as antioxidant and anti-inflammatory agents (Modak et al., 2007; Mukherjee et al., 2013). It is currently estimated that $75 \%-80 \%$ of individuals worldwide depend on herbal remedies for some of their healthcare needs (Ekor, 2014; Karunamoorthi et al., 2013; Kumar et al., 2014).

One of several medicinal herbs traditionally used to treat diabetes is Coccinia grandis (L.) Voigt. This plant has been widely used by the people of India and Sri Lanka for generations to treat various diseases (Attanayake et al., 2016). Coccinia grandis contains phytochemicals such as cephalandrine a, cephalandrine b, cephalandrol, lupeol, taraxerol, $\beta$-sitosterol, tritriacontane, taraxerone, and stigmast-7en-3-one (Tupe et al., 2015). Each part of this plant has been studied either as a single extract or even in combination with other plants or with oral hypoglycemic agents for its antidiabetic function. A number of findings have been published on the mechanism of action of $C$. grandis in lowering blood glucose levels.

Plant extracts have been used not only in single formulas but also in combinations to increase efficacy and decrease side effects. This combination approach provides effective glycemic control for diabetes treatment (Bell, 2013; Sekar et al., 2019). Combinations of two or more extracts often exert synergistic pharmacological effects. In this review, we discuss the antidiabetic effect of $C$. grandis and provide insight into its mechanism of action. We also address the synergistic impact of combining extracts of this plant with those of other plants or with oral antidiabetic drugs. Electronic databases (PubMed and Google Scholar) were used to search for relevant articles published from 1988 to 2020 with the keywords "antidiabetic/ antihyperglycemic activity of Coccinia grandis," "Coccinia indica," "Cephalandra indica," "ivy gourd," "combination effect," and "antidiabetic synergistic effect."

\section{PLANT IDENTITY}

Coccinia grandis (L.) Voigt or ivy/little gourd (in English) belongs to the family Cucurbitaceae. It is a creeping plant that can climb quickly over trees, shrubs, and fences (Wasantwisut and Viriyapanich, 2003). According to the scientific nomenclature, some synonyms for $C$. grandis are Coccinia cordifolia, C. indica, C. indica Naud., and Bryonia grandis (Holstein, 2015). Coccinia grandis originates from tropical areas of Asia and Africa. This plant thrives in Thailand, India, Malaysia, Indonesia, and the Philippines. People in different countries label this plant with specific local names, for example, kundree, olekavi, and telacucha (India), tum leung (Thailand), papasan and boluteke (Indonesia), and pepasan (Malaysia) (Jamwal and Kumar, 2016; Sakharkar and Chauhan, 2017; Wasantwisut and Viriyapanich, 2003). The taxonomic classification of C. grandis is the following (Monalisa et al., 2014):
Kingdom: Plantae.

Division: Tracheophyta.

Class: Magnoliopsida.

Order: Cucurbitales.

Family: Cucurbitaceae.

Genus: Coccinia grandis Wight \& Arn.

Species: Coccinia grandis (L.) Voigt.

The leaf structure ranges from pentagon to heart-like, and the leaves, arranged alternately along the length of the stem (Fig. 1), have a hairless upper surface and a hairy lower surface (Pekamwar et al., 2013). The flowers of C. grandis are white, large, and star shaped, while the fruits are soft and green. The fruit is ovate to ellipsoid in shape and becomes bright red when ripe (Ediriweera and Ratnasooriya, 2009). Coccinia grandis is a dioecious plant, so if seeds and fruit are required, both male and female plants should be planted. At $20^{\circ} \mathrm{C}$, the seeds normally germinate in 2-4 weeks (Waisundara et al., 2015). Coccinia grandis has been utilized as a herbal medicine in India for hundreds of years. It has also been recorded in the Ayurvedic medical system (Wakte and Patil, 2019).

\section{PHYTOCHEMICAL CONSTITUENTS}

Coccinia grandis is a plant with bioactive phytochemicals that offer many advantages in the treatment of diabetes mellitus. Some researchers have demonstrated the phytochemical content

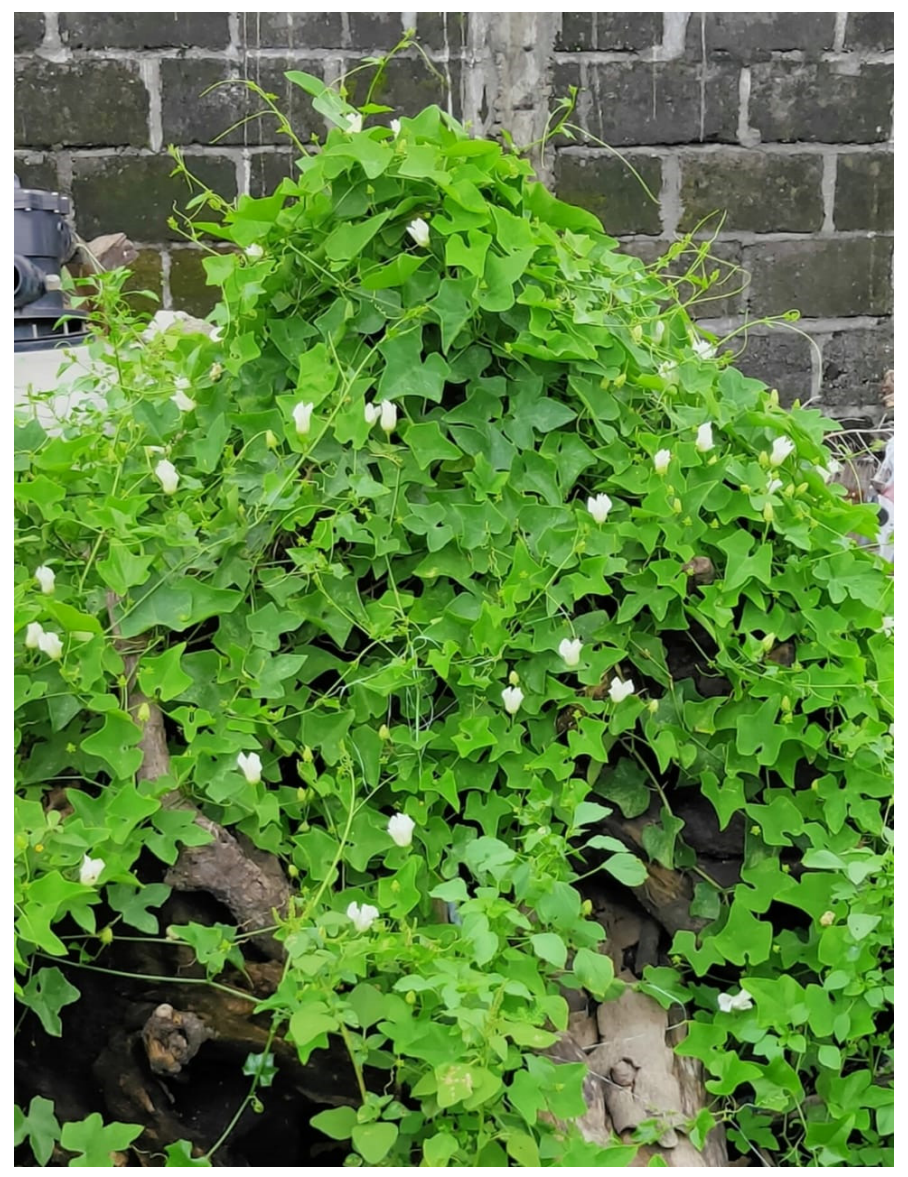

Figure 1. Coccinia grandis (L.) Voigt. 
of this plant. Cephalandrine A, cephalandrine B, cephalandrol, $\beta$-sitosterol, and triacontane were discovered in the ethanolic extract of leaves and aerial parts of $C$. grandis (Deokate and Khadabadi, 2011), while rutin, quercetin-3-O-neohesperidoside, kaempferol-3-O-rutinoside, kaempferol-3- $O$-neohesperidoside, kaempferol-3-O-glucoside, kaempferol-hexoside, oleuropein, and ligstroside were found in the methanolic extract of the leaves (Al-Madhagy et al., 2019). The existence of quercetin in the extract of $C$. grandis aerial parts was also reported by Randhawa et al. (2015). In the root extract, the presence of lupeol, $\beta$-sitosterol, $\beta$-amyrin, coccinioside-k, stigmast-7-en-3-one, flavonoid glycoside ombuin, 3-O-arabinofuranoside, and 3-O- $\beta$ $(\alpha$-l-arabinopyranosyl)- $(1 \rightarrow 2)-\beta$-d-glucopyranosyl- $(1 \rightarrow 3)$ $\beta$-hydroxylup-20(29)-en-28-oic acid was reported (Deokate and Khadabadi, 2011). The methanolic fruit extract contained 2-methoxy-4-vinylphenol, phenol-2-methoxy-5(1-propenyl), undecanol, 2(3h)-furanone, phenol, 3,7,11,15-tetramethyl-2hexadecen-1-ol, 2.4-bis(1,1-dimethylethyl), benzofuranone, 2-methyl-z,z-3, 13-octadecadienol 9,12-octadecadienoic acid, hexadecanoic acid methyl ester, $\beta$-sitosterol acetate, tocopherol, stigmatosterol, ethisteron, campoesterol, and campesterol. Some phytochemicals found in the aqueous fruit extract were hexadecanoic acid methyl ester, dodecanedioic acid, isosteviol, biphenyl, $\alpha$-tocopherol, hexadecanoic acid, n-pentadecanoic acid, oleic acid, linoleic acid, and lukianol (Kondhare and Lade, 2017).

Among the phenolic groups, flavonoids are the most abundant and are known to have potential antidiabetic activity (Mukhopadhyay and Prajapati, 2015; Patra and Chua, 2011). Flavonoids comprise more than 4,000 different compounds that occur naturally in plants (Jasmin and Jaitak, 2019). Some flavonoids play a role in reducing hyperglycemia through the increased proliferation of $\beta$-cells, stimulation of insulin secretion, reduced apoptosis, and control of liver glucose metabolism (AL-Ishaq et al., 2019). As shown in Figure 2, four flavonoid compounds have been identified in C. grandis extract, namely, quercetin (1), kaempferol (2), ombuin (3), and rutin (4).

One of the flavonoid compounds most studied for its antidiabetic activity is quercetin. This compound is also able to overcome complications related to diabetes mellitus. The mechanism of action by which quercetin and its glycosides exert antidiabetic activity has been reported previously and is presented in Figure 3. In human intestinal Caco-2 cells, quercetin inhibited glucose transporter 2 (GLUT2) and decreased glucose and fructose uptake by $75 \%$ (Kwon et al., 2007). Quercetin was also reported to inhibit the activity of two hydrolytic enzymes ( $\alpha$-amylase and $\alpha$-glucosidase), which degrade carbohydrates to simple sugars. This mechanism delayed the digestion of carbohydrates and controlled postprandial blood glucose (Kumar et al., 2013; Limanto et al., 2019). Pancreatic $\beta$-cell protection against oxidative stress is another mechanism by which quercetin exhibits antidiabetic activity. Oxidative stress results from reactive oxygen species (ROS) overproduction and causes damage to the $\beta$-cells in the pancreas. The treatment of streptozotocin (STZ)-induced diabetic rats with quercetin protected $\beta$-cells directly through reduced levels of nitric oxide and malondialdehyde (MDA) and indirectly through increased antioxidant enzymes activity. In this study, insulin secretion was found to be increased (Adewole et al., 2007). The 5' adenosine monophosphate-activated protein kinase (AMPK) pathway was induced by quercetin glycoside extracted from Vaccinium vitis-idaea (Eid et al., 2010). An increase in glucose transporter 4 (GLUT4) expression was observed in diabetic rats treated with quercetin. This increase in GLUT4 expression stimulated the uptake of glucose in muscle cells (Alam et al., 2014). The liver is one of the organ targets of antidiabetic drugs that lower the blood glucose level. Hyperglycemia occurs with hepatic glucose overproduction in a process called gluconeogenesis. Quercetin suppressed gluconeogenesis in an AMPK-dependent manner by inhibiting the glucose-6-phosphate dehydrogenase (G6PDH) enzyme in the isolated perfused liver and hepatoma H4II cells (Eid et al., 2015; Gasparin et al., 2003). Glucose uptake in the liver occurred by

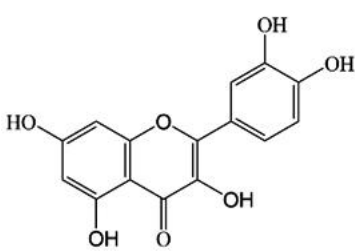

(1)

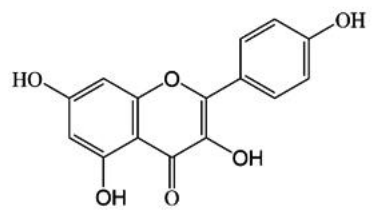

(2)

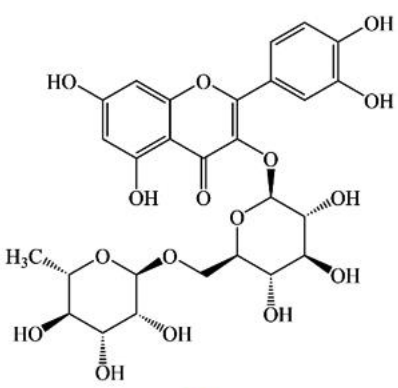

(4)<smiles>COc1cc(O)c2c(=O)c(O)c(-c3ccc(OC)c(O)c3)oc2c1</smiles>

(3)

Figure 2. Flavonoid compounds found in $C$. grandis extracts. 


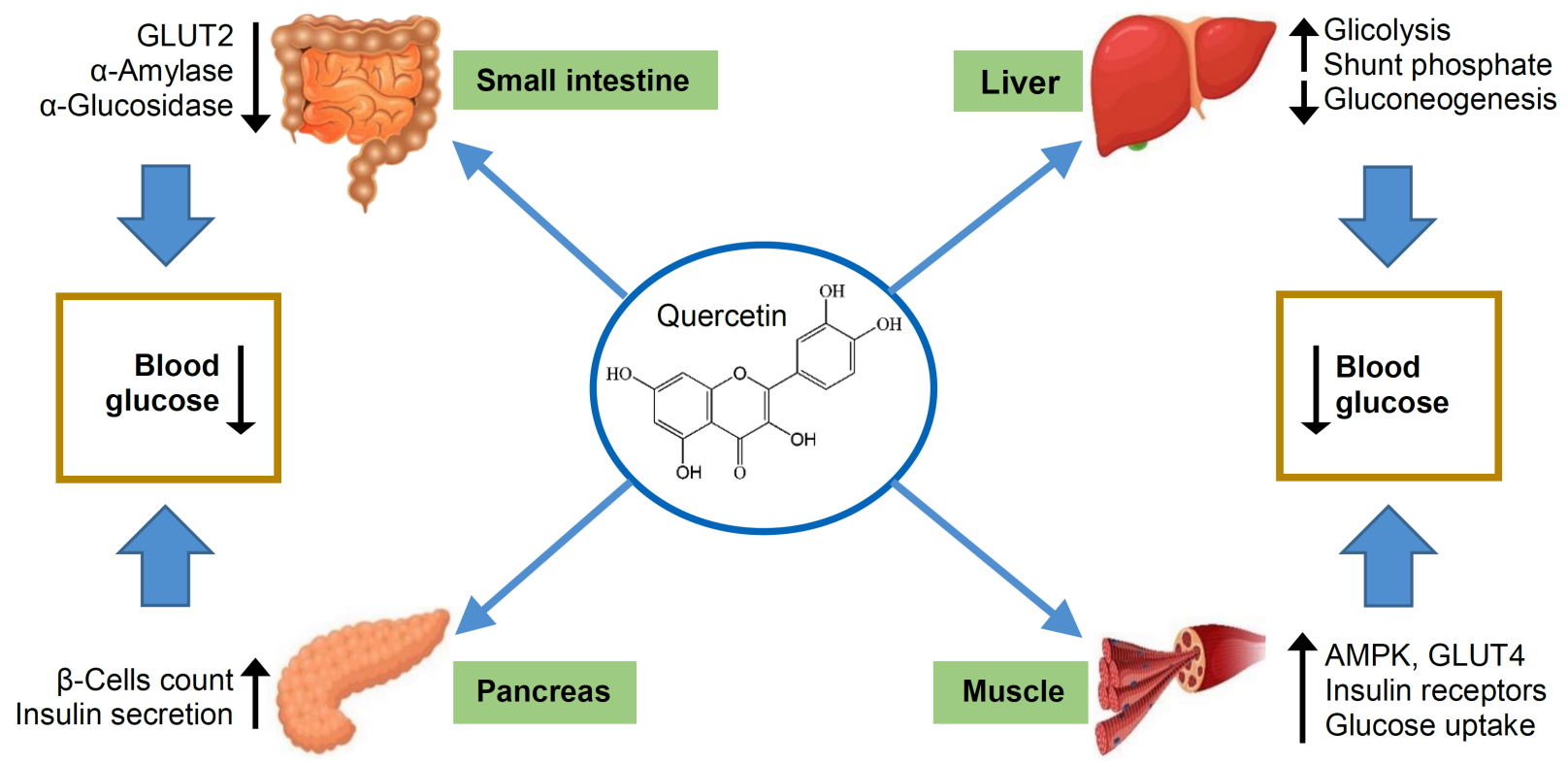

Figure 3. Schematic overview of the antidiabetic activity of quercetin, the main flavonoid in C. grandis. GLUT2: glucose transporter 2, AMPK: 5 ' adenosine monophosphate-activated protein kinase, GLUT4: glucose transporter $4, \uparrow:$ increase, and $\downarrow$ : decrease.

stimulating the activity of key enzymes that participated in glycolysis and the pentose phosphate pathway (Yang et al., 2018).

\section{ANTIDIABETIC ACTIVITY}

Chronic hyperglycemia is the main characteristic of diabetes mellitus, which is caused by imperfections in the secretion and/or action of insulin (American Diabetes Association, 2009). The presence of insulin as an anabolic hormone can generate carbohydrate, lipid, and protein metabolic abnormalities (Kharroubi and Darwish, 2015). Preclinical studies regarding the antidiabetic activities of $C$. grandis have been previously reported in the literature. The mechanisms by which $C$. grandis exerts antidiabetic activity have been proposed and summarized in Table 1. These mechanisms of action include stimulation of insulin secretion, regeneration of $\beta$-cells, restoration of antioxidant enzymes, enhancement of glucose uptake, regulation of metabolic enzymes, amelioration of lipid profiles, and inhibition of digestive enzymes. Here we summarize how $C$. grandis exerts antidiabetic activity via the aforementioned mechanisms of action.

\section{Pancreatic $\beta$-cell regeneration and increased insulin secretion}

In the pancreatic islets, also known as islets of Langerhans, insulin is produced by $\beta$-cells (Da Silva Xavier, 2018). The function of $\beta$-cells can be affected by hyperglycemia that involves complex and multifactorial mechanisms. Some evidence suggests that the mechanisms involved include ROS production, gene transcription alteration, and protein-expression-mediated oxidative stress and increased $\beta$-cell apoptosis (Alsahli and Gerich, 2010). Regeneration of pancreatic cells and restoration of insulin secretion are assisted by reduced intact free radicals and increased antioxidant enzyme activity. In several studies, $C$. grandis extract was discovered to decrease blood glucose levels by regenerating $\beta$-cells and increasing insulin secretion. According to Sudha et al. (2011), the water, chloroform
$(60 \%)$, and ethanol $(70 \%)$ fruit extracts of $C$. grandis $[250 \mathrm{mg} / \mathrm{kg}$ body weight (b.w.)] lowered the blood glucose levels of diabetic rats induced by alloxan in 7 hours. Pal et al. (2013) found that giving the $C$. grandis mother tincture $(750 \mu \mathrm{l} / \mathrm{kg}$ b.w.) to STZ- induced diabetic rats for 3 weeks stimulated insulin secretion and also $\beta$-cell regeneration in the pancreatic islets, thus decreasing blood glucose levels. A mother tincture is a type of homeopathic medicine made from specific plant or animal extracts. In order to make a mother tincture, plant or animal material is extracted with alcohol or water in a particular ratio (Banerjee, 2002; Scheepmaker and Gower, 2011). Enhancement of insulin expression was observed when diabetic rats induced by high-fat-fructose and STZ were given the mother tincture or its active ingredients, i.e., 6-centesimal (6C) and 30-centesimal (30C). In this research, a dose of $20 \mu \mathrm{l} / 100 \mathrm{~g}$ b.w. was applied twice daily for 30 days. Centesimal is a term of homeopathic dilution in which an amount of the mother tincture is diluted with alcohol or distilled water by a factor of 100 at each stage and then vigorously shaken ("succussion") in a new vial (Sampath et al., 2013). The administration of the water extract of $C$. grandis leaves $(0.75 \mathrm{~g} / \mathrm{kg}$ b.w.) orally to diabetic rats induced by STZ for 30 days revealed that the serum insulin, C-peptide, islet diameter, and islet count were increased significantly (Attanayake et al., 2015). The same findings were also confirmed when alloxan-induced rats were given the $C$. grandis leaf aqueous extract $(0.75 \mathrm{~g} / \mathrm{kg}$ b.w., orally) for 30 days (Attanayake et al., 2019).

Insulin secretion is also affected by the excessive secretion of the growth hormone $(\mathrm{GH})$ produced by the pituitary gland. This hormone inhibits insulin secretion by damaging the pancreatic $\beta$-cells. Releasing factors and inhibitory factors (IF) released by hypothalamic neurons are responsible for $\mathrm{GH}$ secretion. Rastogi et al. (1988) revealed that the administration of the $C$. grandis mother tincture (usually prepared as homeopathic therapy, in $41 \%$ alcohol v/v) to diabetic rats induced by alloxan 
Table 1. Preclinical study of C. grandis extracts.

\begin{tabular}{|c|c|c|c|c|c|}
\hline Plant extract & Treated subject & $\begin{array}{c}\text { Dose (administration } \\
\text { route) }\end{array}$ & Duration & Observed effects & References \\
\hline $\begin{array}{c}\text { Homeopathic mother } \\
\text { tincture (in } 41 \% \text { alcohol } \\
\mathrm{v} / \mathrm{v} \text { ) }\end{array}$ & $\begin{array}{l}\text { Diabetic rats induced by } \\
\text { alloxan }\end{array}$ & $\begin{array}{l}25,50,75,100 \mu \mathrm{ml} / 100 \\
\text { g b.w. [peroral or } \\
\text { intraperitoneal (i.p.)] }\end{array}$ & 30 days & $\begin{array}{c}\downarrow \text { blood glucose, } \\
\uparrow \text { pancreatic } \beta \text {-cell counts }\end{array}$ & $\begin{array}{l}\text { Rastogi et al. } \\
\text { (1988) }\end{array}$ \\
\hline $\begin{array}{c}\text { Ethanolic }(60 \%) \text { extract } \\
\text { of leaves }\end{array}$ & $\begin{array}{l}\text { Diabetic rats induced by } \\
\text { STZ }\end{array}$ & 200 mg/kg b.w. (peroral) & 90 minutes & $\begin{array}{c}\downarrow \text { blood glucose, } \\
\downarrow \text { glucose-6-phosphatase activity, } \\
\downarrow \text { fructose-1,6-bisphosphatase activity, } \\
\uparrow \text { G6PDH activity } \\
\downarrow \text { blood glucose }\end{array}$ & $\begin{array}{l}\text { Shibib et al. } \\
\quad(1993)\end{array}$ \\
\hline $\begin{array}{l}\text { Extract of fruits } \\
\text { containing pectin }\end{array}$ & Normoglycemic rats & $\begin{array}{l}\text { Fruit extract (2\%) along } \\
\text { with the diet (peroral) }\end{array}$ & 45 days & $\begin{array}{c}\uparrow \text { hepatic glycogen, } \\
\uparrow \text { hexokinase activity, } \\
\uparrow \text { glycogen synthetase activity, } \\
\downarrow \text { glycogen phosphorylase activity }\end{array}$ & $\begin{array}{l}\text { Kumar et al. } \\
\quad(1993)\end{array}$ \\
\hline $\begin{array}{c}\text { Ethanolic (95\%) extract } \\
\text { of leaves }\end{array}$ & $\begin{array}{l}\text { Diabetic rats induced by } \\
\text { STZ }\end{array}$ & 200 mg/kg b.w. (peroral) & 45 days & $\begin{array}{c}\downarrow \text { blood glucose, } \\
\downarrow \text { glycosylated hemoglobin, } \\
\uparrow \text { total hemoglobin, } \\
\uparrow \text { plasma insulin, } \\
\uparrow \text { hexokinase activity, } \\
\uparrow \text { lipogenic enzymes activity, } \\
\downarrow \text { gluconeogenic enzymes }\end{array}$ & $\begin{array}{r}\text { Venkateswaran } \\
\text { and Pari (2002) }\end{array}$ \\
\hline Extract of aqueous stems & Rat L8 myoblasts & $0.5-2.0 \mathrm{mg} / \mathrm{ml}$ & 24 hours & $\begin{array}{c}\uparrow 2 \text {-DG uptake, } \\
\uparrow \text { GLUT1 expression }\end{array}$ & $\begin{array}{l}\text { Purintrapiban } \\
\text { et al. (2006) }\end{array}$ \\
\hline Aqueous leaves extract & $\begin{array}{l}\text { Diabetic rats induced by } \\
\text { alloxan }\end{array}$ & Not mentioned (peroral) & 21 days & $\begin{array}{c}\downarrow \text { blood glucose, } \\
\downarrow \text { TC, TG, VLDL, and LDL }\end{array}$ & $\begin{array}{l}\text { Manjula and } \\
\text { Ragavan } \\
(2007)\end{array}$ \\
\hline $\begin{array}{l}\text { n-Hexane, chloroform, } \\
\text { ethyl acetate, and } \\
\text { n-butanol fruits extract }\end{array}$ & $\begin{array}{l}\text { Diabetic rats induced by } \\
\text { STZ }\end{array}$ & 200 mg/kg b.w. (peroral) & 30 days & $\downarrow$ blood glucose & (Shakya, 2008) \\
\hline $\begin{array}{c}\text { Ethanolic }(95 \%) \text { aerial } \\
\text { parts extract }\end{array}$ & $\begin{array}{l}\text { Diabetic rats induced by } \\
\text { STZ }\end{array}$ & $\begin{array}{l}100 \text { and } 200 \mathrm{mg} / \mathrm{kg} \text { b.w. } \\
\text { (peroral) }\end{array}$ & 15 days & $\begin{array}{c}\downarrow \text { serum glucose, } \\
\downarrow \text { b.w., } \\
\uparrow \text { liver glycogen, } \\
\downarrow \text { TC, TG, and LDL, } \\
\uparrow \text { HDL, } \\
\downarrow \text { serum glutamic oxaloacetic } \\
\text { transaminase (SGOT), serum glutamic } \\
\text { pyruvic transaminase (SGPT), and } \\
\text { alkaline phosphatase (ALP) }\end{array}$ & $\begin{array}{l}\text { Balaraman } \\
\text { et al. }(2010)\end{array}$ \\
\hline $\begin{array}{l}\text { Hydroalcoholic (1:1) } \\
\text { fruits extract }\end{array}$ & $\begin{array}{l}\text { Diabetic rats induced by } \\
\text { alloxan }\end{array}$ & 200 mg/kg b.w. (peroral) & 14 days & $\begin{array}{c}\downarrow \text { blood glucose, } \\
\downarrow \text { urea, } \\
\uparrow \text { HDL, } \\
\downarrow \text { TC, TG, VLDL, and LDL }\end{array}$ & $\begin{array}{l}\text { Gunjan et al. } \\
\quad \text { (2010) }\end{array}$ \\
\hline $\begin{array}{l}\text { Methanolic }(50 \%) \\
\text { extract of leaves }\end{array}$ & $\begin{array}{l}\alpha \text {-Amylase enzyme (in } \\
\text { vitro) }\end{array}$ & $10 \mathrm{ml} / \mathrm{g}$ dry weight & - & Showed enzyme inhibitory activity & $\begin{array}{l}\text { Jaiboon et al. } \\
\qquad(2010)\end{array}$ \\
\hline $\begin{array}{c}\text { Methanolic extract of } \\
\text { leaves }\end{array}$ & $\begin{array}{l}\text { Swiss albino mice given } 2 \\
\mathrm{~g} / \mathrm{kg} \text { b.w. of glucose after } \\
\text { extracts administration }\end{array}$ & $\begin{array}{l}50-400 \mathrm{mg} / \mathrm{kg} \text { b.w. } \\
\text { (peroral) }\end{array}$ & $\begin{array}{l}1 \text { hour prior } \\
\text { to extracts } \\
\text { administration }\end{array}$ & $\downarrow$ blood glucose & $\begin{array}{l}\text { Sutradhar et al. } \\
\text { (2011) }\end{array}$ \\
\hline
\end{tabular}




\begin{tabular}{|c|c|c|c|c|c|}
\hline Plant extract & Treated subject & $\begin{array}{l}\text { Dose (administration } \\
\text { route) }\end{array}$ & Duration & Observed effects & References \\
\hline $\begin{array}{c}\text { Pet-ether, } \\
\text { ethyl acetate, and } \\
\text { chloroform fractions of } \\
\text { ethanolic leaves extract }\end{array}$ & $\begin{array}{l}\text { Diabetic rats induced by } \\
\text { STZ }\end{array}$ & $150 \mathrm{mg} / \mathrm{kg}$ b.w. (i.p.) & 24 hours & $\begin{array}{c}\downarrow \text { blood glucose, } \\
\downarrow \text { TC, TG }\end{array}$ & $\begin{array}{l}\text { Islam et al. } \\
\quad(2011)\end{array}$ \\
\hline $\begin{array}{c}\text { Ethanolic }(64 \%) \text { leaves } \\
\text { extract }\end{array}$ & $\begin{array}{l}\text { Diabetic rats induced by } \\
\text { STZ }\end{array}$ & 200 mg/kg b.w. (peroral) & 90 minutes & $\begin{array}{c}\downarrow \text { blood glucose, } \\
\downarrow \text { FFA, } \\
\downarrow \text { liver arginase activity }\end{array}$ & $\begin{array}{l}\text { Shibib et al. } \\
\quad(2012)\end{array}$ \\
\hline Mother tincture & $\begin{array}{l}\text { Diabetic rats induced by } \\
\text { STZ }\end{array}$ & $\begin{array}{c}750 \mu \mathrm{l} / \mathrm{kg} \text { b.w. } \\
\text { (peroral) }\end{array}$ & 3 weeks & $\begin{array}{c}\downarrow \text { blood glucose, } \\
\uparrow \text { b.w., } \\
\uparrow \beta \text {-cells regeneration, } \\
\downarrow \text { glucose uptake in } 3 \mathrm{~T} 3 \text { cells }\end{array}$ & $\begin{array}{l}\text { Pal et al. } \\
\text { (2013) }\end{array}$ \\
\hline $\begin{array}{l}\text { Homeopathic mother } \\
\text { tincture }\end{array}$ & $\begin{array}{l}\text { Diabetic rats induced by } \\
\text { high fat, high fructose, and } \\
\text { STZ }\end{array}$ & $\begin{array}{c}\text { 6-centesimal and } \\
\text { 30-centesimal at dose of } \\
20 \mu 1 / 100 \mathrm{~g} \text { b.w. (peroral) }\end{array}$ & 30 days & $\begin{array}{c}\downarrow \text { blood glucose, } \\
\uparrow \text { insulin, } \\
\downarrow \text { TC, TG, and LDL, } \\
\uparrow \text { HDL levels, } \\
\uparrow \text { Akt mRNA and protein, } \\
\uparrow \text { GLUT4 }\end{array}$ & $\begin{array}{l}\text { Sampath et al. } \\
\text { (2013) }\end{array}$ \\
\hline Aqueous leaves extract & $\begin{array}{l}\text { Diabetic rats induced by } \\
\text { alloxan }\end{array}$ & $\begin{array}{l}0.25-2.00 \mathrm{~g} / \mathrm{kg} \text { b.w. } \\
\text { (peroral) }\end{array}$ & 4 hours & $\begin{array}{l}\downarrow \text { blood glucose, } \\
\uparrow \text { glucose tolerance }\end{array}$ & $\begin{array}{l}\text { Attanayake } \\
\text { et al. }(2013)\end{array}$ \\
\hline $\begin{array}{l}\text { Fruits and extract of } \\
\text { leaves incorporated to } \\
\text { AIN-76 diet }\end{array}$ & $\begin{array}{l}\text { Diabetic rats induced by } \\
\text { STZ }\end{array}$ & $\begin{array}{c}5 \% \text { and } 10 \% \text { of extract in } \\
\text { the diet }\end{array}$ & 45 days & $\begin{array}{c}\downarrow \text { blood glucose, } \\
\uparrow \text { glucose tolerance, } \\
\uparrow \text { b.w., } \\
\downarrow \text { urine sugar, } \\
\downarrow \text { kidney index and glomerular } \\
\text { filtration rate }\end{array}$ & $\begin{array}{l}\text { Gurukar et al. } \\
\quad \text { (2013) }\end{array}$ \\
\hline $\begin{array}{l}\text { Decoction, alcohol } \\
\text { maceration, water } \\
\text { maceration, and Soxhlet } \\
\text { extraction of fruits }\end{array}$ & $\begin{array}{l}\alpha \text {-Glucosidase enzyme (in } \\
\text { vitro) }\end{array}$ & $\begin{array}{l}\text { Various concentrations of } \\
\text { extract }\end{array}$ & - & Exhibited enzyme inhibitory activity & $\begin{array}{l}\text { Alagar et al. } \\
\text { (2014) }\end{array}$ \\
\hline Leaves decoction & $\begin{array}{l}\text { Diabetic rats induced by } \\
\text { alloxan }\end{array}$ & $3 \mathrm{ml} / \mathrm{kg}$ b.w. (peroral) & 14 days & $\begin{array}{l}\downarrow \text { blood glucose, } \\
\qquad \text { TC, } \\
\downarrow \downarrow \text { urea, }\end{array}$ & $\begin{array}{l}\text { Islam et al. } \\
\quad \text { (2014) }\end{array}$ \\
\hline $\begin{array}{l}\text { Aqueous extract of } \\
\text { leaves extract }\end{array}$ & $\begin{array}{l}\text { Diabetic rats induced by } \\
\text { STZ }\end{array}$ & $0.75 \mathrm{~g} / \mathrm{kg}$ b.w. (peroral) & 30 days & $\begin{array}{c}\uparrow \text { SGOT, SGPT, and total protein } \\
\downarrow \text { Hemoglobin A1c (HbA1c), } \\
\downarrow \text { fructosamine, } \\
\uparrow \text { serum insulin and C-peptide, } \\
\uparrow \text { islet diameter, islet count, and islet } \\
\text { regeneration }\end{array}$ & $\begin{array}{l}\text { Attanayake } \\
\text { et al. }(2015)\end{array}$ \\
\hline $\begin{array}{l}\text { Methanolic extract of } \\
\text { fruit and callus }\end{array}$ & $\begin{array}{l}\alpha \text {-Amylase enzyme } \\
(\text { in vitro })\end{array}$ & $\begin{array}{l}\text { Various concentrations of } \\
\text { extract }\end{array}$ & - & $\begin{array}{l}\text { Exhibited enzyme inhibitory activity } \\
\text { and DPPH radicals scavenging activity }\end{array}$ & $\begin{array}{c}\text { Patel and } \\
\text { Ishnava (2015) }\end{array}$ \\
\hline
\end{tabular}




\begin{tabular}{|c|c|c|c|c|c|}
\hline Plant extract & Treated subject & $\begin{array}{l}\text { Dose (administration } \\
\text { route) }\end{array}$ & Duration & Observed effects & References \\
\hline Ethanolic leaves extract & $\begin{array}{c}\alpha \text {-Amylase enzyme } \\
\text { (in vitro), yeast cells } \\
\text { (in vitro), and diabetic rats } \\
\text { induced by STZ }\end{array}$ & $\begin{array}{l}50-500 \mathrm{mg} / \mathrm{kg} \text { b.w. } \\
\text { (peroral) }\end{array}$ & 21 days & $\begin{array}{c}\text { Exhibited enzyme inhibitory activity, } \\
\uparrow \text { glucose uptake, } \\
\downarrow \text { blood glucose, } \\
\uparrow \text { serum insulin, } \\
\uparrow \text { glycogen and HDL, } \\
\downarrow \text { TC, TG, LDL, and VLDL, } \\
\uparrow \text { SOD, CAT, and reduced glutathione, } \\
\downarrow \text { necrosis, } \\
\uparrow \text { population and size of islets }\end{array}$ & $\begin{array}{l}\text { Mohammed } \\
\text { et al. }(2016)\end{array}$ \\
\hline $\begin{array}{c}\text { Aqueous extract of } \\
\text { leaves }\end{array}$ & $\begin{array}{c}\text { Diabetic rats induced by } \\
\text { STZ }\end{array}$ & $0.75 \mathrm{~g} / \mathrm{kg}$ b.w. (peroral) & 30 days & $\begin{array}{c}\downarrow \text { blood glucose, } \\
\downarrow \text { ALT, AST, and ALP, } \\
\downarrow \text { MDA, } \\
\uparrow \text { GSH, GR, GPx, and GST, } \\
\uparrow \text { HDL-C levels } \\
\downarrow \text { TC, LDL-C, VLDL-C, and TG }\end{array}$ & $\begin{array}{l}\text { Attanayake } \\
\text { et al. }(2018)\end{array}$ \\
\hline $\begin{array}{l}\text { Chloroform extract of } \\
\text { fruits }\end{array}$ & $\begin{array}{l}\text { Diabetic rats induced by } \\
\text { STZ-nicotinamide }\end{array}$ & $250 \mathrm{mg} / \mathrm{kg}$ b.w. (peroral) & 7 days & $\downarrow$ blood glucose & $\begin{array}{l}\text { Kaushik et al. } \\
\quad \text { (2017) }\end{array}$ \\
\hline $\begin{array}{l}\text { Methanolic extract of } \\
\text { fruits }\end{array}$ & $\begin{array}{l}\text { In vitro antioxidant, } \\
\text { antiglycation, } \\
\text { cytoprotective effect, and } \\
\text { insulin secretion assays } \\
\text { developed to the extract }\end{array}$ & Various concentrations & - & $\begin{array}{l}\text { Exhibited radical-scavenging } \\
\text { activity, antiglycation potential, and } \\
\text { insulinotropic property }\end{array}$ & $\begin{array}{l}\text { Meenatchi } \\
\text { et al. }(2017)\end{array}$ \\
\hline $\begin{array}{l}\text { Mother tincture and its } \\
\text { potencies of } 6 \mathrm{C} \text { and } 30 \mathrm{C}\end{array}$ & $\begin{array}{l}\text { Diabetic rats induced by } \\
\text { STZ-nicotinamide }\end{array}$ & $\begin{array}{l}2 \mathrm{ml} / \mathrm{kg} \text { b.w. orally } \\
\text { (peroral) }\end{array}$ & 30 days & $\begin{array}{l}\downarrow \text { serum glucose, } \uparrow \text { serum insulin, } \\
\downarrow \text { TBARS, nitrite, and advanced } \\
\text { glycation end product’s levels, } \\
\uparrow \text { SOD and GSH }\end{array}$ & $\begin{array}{l}\text { Kishore and } \\
\text { Singh (2017) }\end{array}$ \\
\hline $\begin{array}{l}\text { Aqueous leaves and } \\
\text { stems extract }\end{array}$ & $\begin{array}{c}\alpha \text {-Amylase and } \\
\alpha \text {-glucosidase (in vitro) }\end{array}$ & Various concentrations & - & Exhibited enzyme inhibitory activity & $\begin{array}{l}\text { Pulbutr et al. } \\
\text { (2017) }\end{array}$ \\
\hline $\begin{array}{l}\text { Ethanolic extracts of } \\
\text { fruits (mature unripe) }\end{array}$ & $\begin{array}{c}\text { Diabetic rats induced by } \\
\text { STZ }\end{array}$ & $\begin{array}{l}125-750 \mathrm{mg} / \mathrm{kg} \text { b.w. } \\
\text { (peroral) }\end{array}$ & 30 days & $\begin{array}{c}\downarrow \text { blood glucose, } \downarrow \text { HbA1c, } \\
\uparrow \text { insulin, } \\
\uparrow \text { glycogen, } \\
\uparrow \text { hexokinase activity, } \\
\uparrow \text { G6PDH, } \\
\downarrow \text { glucose-6-phosphatase, } \\
\downarrow \text { fructose-1,6-bisphosphatase }\end{array}$ & $\begin{array}{l}\text { Packirisamy } \\
\text { et al. }(2018)\end{array}$ \\
\hline Aqueous leaves extract & $\begin{array}{l}\text { Diabetic rats induced by } \\
\text { alloxan }\end{array}$ & 0.75 g/kg b.w. (peroral) & 30 days & $\begin{array}{c}\uparrow \text { serum insulin, } \\
\uparrow \text { C-peptide, } \\
\uparrow \text { islets counts, } \\
\uparrow \beta \text {-cells regeneration }\end{array}$ & $\begin{array}{l}\text { Attanayake } \\
\text { et al. }(2019)\end{array}$ \\
\hline $\begin{array}{l}\text { Mother tincture and its } \\
\text { potencies of } 6 \mathrm{C} \text { and } 30 \mathrm{C}\end{array}$ & $\begin{array}{l}\text { Diabetic rats with } \\
\text { nephropathy induced by } \\
\text { STZ }\end{array}$ & $2 \mathrm{ml} / \mathrm{kg}$ b.w. (peroral) & 75 days & $\begin{array}{c}\downarrow \text { blood glucose, } \uparrow \text { b.w., } \\
\uparrow \text { renal function, } \\
\downarrow \text { TC, TG, LDL, and VLDL, } \\
\uparrow \text { HDL, } \\
\downarrow \text { TBARS level, } \\
\uparrow \text { GSH and SOD }\end{array}$ & $\begin{array}{l}\text { Kishore and } \\
\text { Singh (2019) }\end{array}$ \\
\hline
\end{tabular}


with doses of $25-100 \mu \mathrm{ml} / 100 \mathrm{~g}$ b.w. for 30 days was observed to normalize blood glucose levels and maintained the levels for 14-20 days after drug withdrawal. Additionally, the pancreatic $\beta$-cell count was also reported to reach the normal range. These effects were probably caused by the release of IF, which inhibited the secretion of $\mathrm{GH}$ from the adenohypophysis, thus regenerating and restoring the $\beta$-cell count.

\section{Restoration of antioxidant enzymes}

Excessive ROS production induces oxidative stress, which is a major factor in the development of diabetes and its complications (Asmat et al., 2016). ROS, including free radicals, can cause oxidation of proteins, peroxidation of lipids, and damage to the enzyme system and cellular organelles (Bansal and Bilaspuri, 2011; Kishore and Singh, 2017). Therefore, an extract with the ability to scavenge free radicals is required in order to minimize oxidative stress (Roy et al., 2013). Preclinical antidiabetic studies revealed that peroral administration of STZ induces oxidative stress by selectively targeting $\beta$-cells of the pancreas via plasma membrane GLUT2 and causes $\beta$-cell destruction. In rats, STZ causes hyperglycemia and oxidative stress (Mao et al., 2015). In an experiment, the methanolic extract of $C$. grandis fruits scavenged free radicals [1,1-Diphenyl-2-picrylhydrazyl (DPPH)] with the half maximal inhibitory concentration ( $\mathrm{IC}_{50}$ ) value of $165.69 \mathrm{mg}$ / $\mathrm{ml}$ (Meenatchi et al., 2017). The extract was also able to scavenge $\mathrm{H}_{2} \mathrm{O}_{2}$ and superoxide anion radicals. The scavenging activity was found to increase with increasing extract concentration. The existence of phenolic and flavonoid compounds in the $C$. grandis fruit extract was found to be responsible for its antioxidant activity.

Oxidative stress may occur due to a mismatch between the antioxidative protective systems in the human body and the formation of ROS, including free radicals. Reduced glutathione (GSH), catalase (CAT), and superoxide dismutase (SOD) are the antioxidant enzymes that have been reported to protect the human body against free radicals (Halliwell, 2009; Oguntibeju, 2019). The levels of these enzymes decreased in diabetic rats, as compared with those in nondiabetic rats. Diabetic rats also had a higher content of thiobarbituric acid-reactive substances (TBARS), which may be attributed to a rise in oxygen free radicals (Kishore and Singh, 2019). Attanayake et al. (2018) discovered that the aqueous extract of $C$. grandis leaves administered to diabetic rats induced by STZ for 30 days was able to decrease the concentration of MDA and to increase the activity of reduced glutathione (GSH), glutathione reductase (GR), glutathione $S$-transferase (GST), and glutathione peroxidase (GPx) in liver homogenates. These results demonstrated that the extract scavenged free radicals that inactivated metabolic enzymes. The mother tincture of $C$. grandis and its dilutions $6 \mathrm{C}$ and $30 \mathrm{C}(2 \mathrm{ml} / \mathrm{kg}$ b.w.) given orally to STZnicotinamide-induced diabetic rats for 30 days increased the activities of antioxidant enzymes (GSH and SOD) and decreased TBARS level (Kishore and Singh, 2017). The same result was also found when the mother tincture of C. grandis, 6C, and 30C ( $2 \mathrm{ml} / \mathrm{kg}$ b.w.) were given to diabetic rats induced by STZ with nephropathy for 75 days (Kishore and Singh, 2019).

\section{Enhancement of glucose uptake}

Glucose disposal is mainly deposited into skeletal muscles, and this process is insulin dependent. Insulin is well known for assisting glucose utilization in muscle cells. To promote the uptake of glucose, insulin recruits GLUT4 to the plasma membrane. Purintrapiban et al. (2006) revealed that water extract of $C$. grandis enhanced the uptake of 2-deoxyglucose (2-DG) in rats L8 myotubes for 16 hours of incubation in a dose-dependent manner. In addition, they revealed that the $C$. grandis water extract promoted glucose transport by increasing the amount of GLUT4 (an insulin-dependent protein highly expressed in fat tissue and skeletal muscle) on the cell surface and increased the synthesis of the glucose transporter 1 (GLUT1) protein. Sampath et al. (2013) studied the effect of the $C$. grandis mother tincture on high-fatfructose- and STZ-induced diabetic rats at a dose of $20 \mu \mathrm{l} / 100 \mathrm{~g}$ b.w. for 30 days. Increased GLUT4 messenger ribonucleic acid (mRNA) was observed in the cytosol, plasma membrane, and gastrocnemius muscle. This led to the increase in the GLUT4 level and enhancing glucose uptake activity.

\section{Regulation of metabolic enzymes}

A low insulin level can affect the catalysis of metabolic reactions by hepatic enzymes. The main enzymes in the gluconeogenesis pathway are glucose-6-phosphatase and fructose1,6-bisphosphatase. When rats developed diabetes, the activity of these enzymes increased substantially. As a result, the concentration of glucose in the blood was elevated. Oral administration of the C. grandis leaf ethanolic extract (60\%) at a dose of $200 \mathrm{mg} / \mathrm{kg}$ b.w. was reported to depress glucose-6-phosphatase and fructose1,6-bisphosphatase enzyme activity in diabetic rats induced by STZ after 18 hours of fasting. This extract was also reported to activate G6PDH in the glucose metabolism pathway (the hexose monophosphate shunt pathway), which resulted in an increase in glucose oxidation (Shibib et al., 1993). In another study, STZinduced diabetic rats were administered an ethanolic (95\%) extract of $C$. grandis leaves (200 mg/kg b.w.) for 45 days. This extract was found to inhibit the glucose-6-phosphatase and fructose-1,6bisphosphatase enzymes in the gluconeogenic pathway and to improve glucose uptake by stimulating hepatic hexokinase in the glycolytic pathway (Venkateswaran and Pari, 2002).

Hexokinase is an insulin-dependent enzyme that plays a key role in the homeostasis of glucose. This enzyme is involved in the glycolytic pathway and metabolism of glucose by adenosine triphosphate to produce glucose-6-phosphate. When hexokinase activity increased, glucose utilization in glycolysis was also increased. The activity of this enzyme was significantly reduced when rats developed diabetes. Consequently, the concentration of glucose in the blood was increased. Kumar et al. (1993) investigated the influence of the $C$. grandis fruit extract ( $2 \%$ along with the diet) on the activity of hexokinase in normoglycemic rats for 45 days. The results showed that pectin from fruit extracts increased glycolysis by activating hexokinase enzyme activity and enhanced the rate of glycogenesis. They also found that pectin from the fruit extracts increased the glycogen synthase activity and decreased the glycogen phosphorylase activity in glycogenolysis. Increased hexokinase and G6PDH activity and increased glycogen content have also been reported by Packirisamy et al. (2018). They revealed that ethanolic extracts of fruits (mature unripe) given orally to STZ-induced diabetic rats at doses of $125-750 \mathrm{mg} /$ $\mathrm{kg}$ b.w. for 30 days inhibited the action of glucose-6-phosphatase and fructose-1,6-bisphosphatase. 


\section{Amelioration of lipid profiles}

Diabetes and dyslipidemia are related remarkably. When rats develop diabetes, the lipid profile is impaired by hyperglycemia, which is accompanied by abnormalities in lipoprotein metabolism. This results in an increase in triacylglycerol (TG), total cholesterol (TC), very low-density lipoprotein (VLDL), and low-density lipoprotein (LDL) and a decrease in high-density lipoprotein (HDL) due to the mobilization of excessive fat from adipose tissues (Bhat et al., 2012). In normal rats, insulin inhibits lipolysis and reduces free fatty acid (FFA) release by suppressing lipase activity. However, the activity of lipase is increased in diabetic rats. Consequently, it stimulates the release of FFA. Thus, more acetyl-CoA and cholesterol are produced during $\beta$-oxidation of FFA(Nasirian et al., 2019). Several studies have shown that giving diabetic rats an extract of $C$. grandis improves their lipid profiles. Manjula and Ragavan (2007) reported decreases in blood glucose, TC, TG, VLDL, and LDL in alloxaninduced diabetic rats when the $C$. grandis aqueous leaf extract was given. A similar result was also obtained by Balaraman et al. (2010), who administered a $95 \%$ ethanolic extract of $C$. grandis aerial parts to STZ-induced diabetic rats in doses of 100 and $200 \mathrm{mg} / \mathrm{kg}$ b.w. for 15 days. Furthermore, a hydroalcoholic (1:1) fruit extract of $C$. grandis at a dose of $200 \mathrm{mg} / \mathrm{kg}$ b.w. for 14 days was reported to increase HDL and decrease TG, LDL, VLDL, and TC levels in alloxan-induced diabetic rats. Attanayake et al. (2018) showed that oral administration of the aqueous leaf extract of $C$. grandis for 30 days in STZ-induced diabetic rats resulted in the reduction of TC, Low-density lipoprotein cholesterol (LDL-C), Very low-density lipoprotein cholesterol (VLDL-C), and TG levels and elevation of High-density lipoprotein cholesterol (HDL-C) level. Most recently, the mother tincture and its dilution at $6 \mathrm{C}$ and $30 \mathrm{C}(2 \mathrm{ml} / \mathrm{kg}$ b.w.) ameliorated the lipid profile, including TC, TG, LDL, VLDL, and HDL, in STZ-induced diabetic rats (Kishore and Singh, 2019).

\section{Inhibition of digestive enzymes}

Reducing postprandial hyperglycemia by inhibiting carbohydrate-degrading enzymes in the gastrointestinal tract is indeed one of the therapies targeted to diabetes mellitus. Extracts with enzyme inhibitory activity delay carbohydrate digestion and prolong the overall digestion time of carbohydrates, resulting in a decrease in glucose absorption (Sy et al., 2017). The hydrolysis of starch to maltose, maltotriose, $\alpha-(1-4)$-oligoglucans, and $\alpha-(1-6)$ oligoglucans is catalyzed by the $\alpha$-amylase enzyme. The mixture of oligosaccharides is degraded into glucose by the $\alpha$-glucosidase enzyme. Therefore, reducing glucose absorption in the digestive tract by inhibiting the activity of these carbohydrate-degrading enzymes is one of the therapeutic approaches for managing diabetes mellitus (Sudha et al., 2011).

The $C$. grandis leaf extract was reported to have potent $\alpha$-amylase and $\alpha$-glucosidase inhibitory activities. Jaiboon et al. (2010) revealed that the methanolic (50\% v/v) extract of $C$. grandis leaves inhibited $\alpha$-amylase enzymatic activity. The inhibitory activity of $\alpha$-amylase by the ethanolic extract of $C$. grandis leaves was also reported by Mohammed et al. (2016) with an $\mathrm{IC}_{50}$ of $78.47 \pm 0.18 \mu \mathrm{g} / \mathrm{ml}$. This activity was higher than that of ethyl acetate and the n-hexane extracts, with $\mathrm{IC}_{50}$ values of $94.65 \pm 0.15$ and $110.27 \pm 0.04 \mu \mathrm{g} / \mathrm{ml}$, respectively. The fruit extract of $C$. grandis obtained by various methods of extraction, i.e., decoction, alcohol maceration, water maceration, and Soxhlet extraction, showed inhibition of $\alpha$-glucosidase activity (Alagar et al., 2014). The methanol extract of $C$. grandis fruits, callus, and different combination mixtures of callus at a concentration of $1.0 \mathrm{mg} / \mathrm{l}$ inhibited $\alpha$-amylase enzymatic activity with inhibition percentages of $54.29 \%, 75.72 \%$, and $80.00 \%$, respectively (Patel and Ishnava, 2015). Pulbutr et al. (2017) revealed that the aqueous extract of leaves and stems of $C$. grandis significantly inhibited $\alpha$-amylase activity with $\mathrm{IC}_{50}$ of $8.09 \pm 0.72$ and $8.06 \pm 1.27 \mathrm{mg} / \mathrm{ml}$, respectively. It also inhibited the action of $\alpha$-glucosidase with $\mathrm{IC}_{50}$ values of $77.66 \pm 9.16 \mu \mathrm{g} /$ $\mathrm{ml}$ and $0.75 \pm 0.11 \mathrm{mg} / \mathrm{ml}$, respectively.

\section{SYNERGISTIC EFFECT AND COMBINATION OF EXTRACTS}

The antidiabetic activity of a plant extract might be increased by combining it with other extracts and/or drugs that have similar activity. The synergistic effect of these combinations can increase efficacy and decrease side effects. Synergism is the effect that occurs when the combined effects of two or more drugs are greater than the sum of their individual effects. This occurs because the phytochemical compounds in the combined extracts act on different targets in the pathogenic process; consequently, the overall therapeutic efficacy is increased (Rasoanaivo et al., 2011). The combination index $(\mathrm{CI})$ has been used frequently to determine the interactions between the components of the combined extracts. This approach was introduced by Chou and Talalay using median effect principles (Chou and Talalay, 1984) and was computerized later using CompuSyn software (Chou, 2006). The formula used for the calculation of the CI was as follows:

$$
\mathrm{CI}=\frac{D_{1(x)}}{E_{1(x)}}+\frac{D_{2(x)}}{E_{2(x)}},
$$

where $D_{1(x)}$ and $D_{2(x)}$ are the concentrations of each extract/drug in combination that produced an $x$ effect and $E_{1(x)}$ and $E_{2(x)}$ are the concentrations of each extract/drug alone that produced the same effect. Synergy, additivity, and antagonism interactions are implied by CI values of $<1,1$, and $>1$, respectively (Wong et al., 2019).

The combination of C. grandis extract with other extracts/ drugs has been mentioned in several publications (Table 2). The combination of $C$. grandis leaves and the Abroma augusta root aqueous extract (300 mg/kg b.w.) exhibited antihyperglycemic and antihyperlipidemic activities better than the single plant extract in STZ-induced albino rats for 8 weeks. These results provide evidence of a synergistic interaction between $C$. grandis and A. augusta (Eshrat, 2003). The synergistic interaction was also reported by Mallick et al. (2007), who combined the $C$. grandis leaf extract and Musa paradisiaca root extract. Both plant materials were extracted in a 2:3 ratio with water and methanol. The combined extract $(1: 1)$ at a dose of $80 \mathrm{mg} / 100 \mathrm{~g}$ b.w. was administered orally to diabetic rats induced by STZ for 14 days. The combined extract exhibited higher antihyperglycemic activity than the single extract in terms of reducing the level of fasting blood glucose and raising the glucose tolerance and the level of serum insulin. In addition, the combined extract greatly increased glucose-6-phosphatase, G6PDH, hexokinase, and glycogen levels in the liver. Further research conducted by Mallick et al. (2009) 
Table 2. The combination of $C$. grandis extracts and synthetic drugs.

\begin{tabular}{|c|c|c|c|c|c|}
\hline C. grandis extracts & Combination with & Diabetic model animals & Dose (administration route) & Duration & References \\
\hline $\begin{array}{c}\text { Water extract of } \\
\text { leaves }\end{array}$ & $\begin{array}{l}\text { Water extract of } A \text {. } \\
\text { augusta roots }\end{array}$ & $\begin{array}{c}\text { Diabetic rats induced by } \\
\text { STZ }\end{array}$ & 300 mg/kg b.w. (peroral) & 8 weeks & Eshrat (2003) \\
\hline $\begin{array}{l}\text { Water-methanol water } \\
\text { extract of leaves }\end{array}$ & $\begin{array}{l}\text { Water-methanol extract of } \\
\text { M. paradisiaca roots }\end{array}$ & $\begin{array}{l}\text { Diabetic rats induced by } \\
\text { STZ }\end{array}$ & $\begin{array}{c}80 \mathrm{mg} / 0.5 \mathrm{ml} \text { olive oil } / 100 \mathrm{~g} \\
\text { b.w. (oral gavage) }\end{array}$ & 14 days & Mallick et al. (2007) \\
\hline $\begin{array}{l}\text { Water-methanol water } \\
\text { extract of leaves }\end{array}$ & $\begin{array}{l}\text { Water-methanol extract of } \\
\text { M. paradisiaca roots }\end{array}$ & $\begin{array}{c}\text { Diabetic rats induced by } \\
\text { STZ }\end{array}$ & $\begin{array}{c}80 \mathrm{mg} / 0.5 \mathrm{ml} \text { olive oil } / 100 \mathrm{~g} \\
\text { b.w. (oral gavage) }\end{array}$ & 14 days & Mallick et al. (2009) \\
\hline Water extract of fruits & $\begin{array}{l}\text { Water extract of } M \text {. } \\
\text { citrifolia fruits }\end{array}$ & $\begin{array}{l}\text { Diabetic rats induced by } \\
\text { alloxan }\end{array}$ & 300 mg/kg b.w. (peroral) & 30 days & Prakash et al. (2010) \\
\hline $\begin{array}{c}\text { Ethanolic extract of } \\
\text { leaves }\end{array}$ & Glibenclamide & $\begin{array}{l}\text { Diabetic rats induced by } \\
\text { alloxan }\end{array}$ & $\begin{array}{l}100,150, \text { and } 200 \mathrm{mg} / \mathrm{kg} \text { b.w. } \\
\text { (peroral) }\end{array}$ & 45 days & Eliza and Usha (2011) \\
\hline $\begin{array}{l}\text { Petroleum ether- } \\
\text { methanol extract of } \\
\text { leaves }\end{array}$ & $\begin{array}{l}\text { Petroleum ether-methanol } \\
\text { extract of Salvadora } \\
\text { oleoides leaves }\end{array}$ & $\begin{array}{l}\text { Diabetic rats induced by } \\
\text { alloxan }\end{array}$ & 150 mg/kg b.w. (peroral) & 15 days & Saklani et al. (2012) \\
\hline $\begin{array}{l}\text { Extract of leaves } \\
\text { from the Green } \\
\text { Chem industry, } \\
\text { Bangalore (Batch No. } \\
\text { CIL/12005) }\end{array}$ & Acarbose & $\begin{array}{l}\text { Diabetic rats induced by } \\
\text {-HFD- low-dose STZ }\end{array}$ & 200 mg/kg b.w. (peroral) & 8 weeks & $\begin{array}{l}\text { Kohli and Kumar } \\
\qquad(2014)\end{array}$ \\
\hline $\begin{array}{l}\text { Extracts of whole } \\
\text { plant methanolic }\end{array}$ & $\begin{array}{c}T . \\
\text { foenum-graecum }(\mathrm{L} .) \\
\text { methanolic extracts }\end{array}$ & $\begin{array}{l}\text { Alloxan-induced diabetic } \\
\text { rats }\end{array}$ & $\begin{array}{c}125 \mathrm{mg} / \mathrm{kg} \text { b.w. (C. grandis) } \\
\text { and } 250 \mathrm{mg} / \mathrm{kg} \text { b.w. (T. foenum- } \\
\text { graecum) (peroral) }\end{array}$ & 21 days & Ruby et al. (2014) \\
\hline $\begin{array}{l}\text { Aqueous leaves } \\
\text { extract }\end{array}$ & $\begin{array}{l}\text { Aqueous extract of } A \text {. } \\
\text { bilimbi L. fruits }\end{array}$ & In vitro study & Ratios of $1: 3,1: 1$, and $3: 1$ & - & Putra et al. (2020) \\
\hline $\begin{array}{c}\text { Ethanolic extract of } \\
\text { leaves }\end{array}$ & Pioglitazone & $\begin{array}{c}\text { Diabetic rats induced by } \\
\text { HFD-STZ }\end{array}$ & 200 mg/kg b.w. (peroral) & 7 weeks & $\begin{array}{c}\text { Basavarajappa et al. } \\
\text { (2020) }\end{array}$ \\
\hline
\end{tabular}

indicated that the combination of the $C$. grandis leaves and $M$. paradisiaca root aqueous-methanol extract was able to modulate the protein involved in the regulation of metabolic disorders as well as diabetes. Interestingly, it also showed a protective effect against diabetes by increasing the capacity of $\beta$-cell regeneration. The aqueous extract of $C$. grandis and Morinda citrifolia fruits $(300 \mathrm{mg} / \mathrm{kg}$ b.w.) reduced serum glucose and increased serum insulin in alloxan-induced diabetic rats in 30 days (Prakash et al., 2010). Synergism was also reported by other researchers who combined whole plant methanolic extracts of $C$. grandis and Trigonella foenum-graecum L. Alloxan-induced diabetic rats were given this combined extract at doses of $125 \mathrm{mg} / \mathrm{kg} \mathrm{b}$.w. (C. grandis) and $250 \mathrm{mg} / \mathrm{kg}$ b.w. (Trigonella foenum-graecum L.) for 21 days (Ruby et al., 2014). The level of blood glucose was found to be decreased significantly. This finding suggested that the combined extract was more active than the single extract. Saklani et al. (2012) found that giving alloxan-induced diabetic rats a petroleum ether-methanol extract of $C$. grandis and Salvadora oleoides leaves (150 mg/kg b.w.) for 15 days decreased blood glucose levels, compared with administration of the standard drug glipizide. Furthermore, the combined extract had a major impact on lipid profiles, alanine aminotransferase/aspartate amino transferase (AST) activity, and serum creatinine and urea levels. Recently, Putra et al. (2020) reported that the aqueous extract of $C$. grandis leaves and Averrhoa bilimbi fruits showed higher in vitro DPPH radical-scavenging and $\alpha$-amylase inhibition activities than that of the single extract.

In addition to the combination with other plant extracts, C. grandis was also combined with antidiabetic drugs as reported by Eliza and Usha (2011), who combined the ethanolic leaf extract of $C$. grandis at doses of 100, 150, and $200 \mathrm{mg} / \mathrm{kg}$ b.w. with the antidiabetic drug glibenclamide $(0.125 \mathrm{mg} / \mathrm{kg} \mathrm{b.w.).} \mathrm{Alloxan-}$ induced diabetic rats were given the extract-drug combination orally at 15 days intervals. After 45 days of therapy, the extractdrug combination lowered the concentration of blood glucose and normalized TC and TG levels. Additionally, GSH and lipid peroxide levels were also reduced. The $C$. grandis leaf extract (200 mg/kg b.w.) combined with acarbose ( $5 \mathrm{mg} / \mathrm{kg}$ b.w.) reduced blood glucose levels compared with the single extract and drug administered to STZ-induced diabetic rats with a high-fat diet (HFD) for 8 weeks. This combination also showed stronger antioxidant activity (SOD, CAT, TBARS, and GSH) than the single extract and drug (Kohli and Kumar, 2014). The combination effect of the C. grandis ethanolic leaf extract and pioglitazone was recently reported by Basavarajappa et al. (2020). The combination of extract (200 mg/kg b.w.) and pioglitazone (7 mg/kg b.w.) was given orally to HFD-fed STZ-induced diabetic rats for 7 weeks. They discovered that the extract-drug combination normalizes blood glucose levels and lipid profiles and decreases oxidative stress more efficiently than a single extract and pioglitazone alone. In rats treated with the extract-drug combination, an improved renal protection effect was also observed.

\section{CONCLUSION}

This review provides comprehensive information regarding the activity of $C$. grandis as an antidiabetic remedy. This plant is a promising agent for treating diabetes mellitus. The mechanism of action of these plant extracts in lowering 
blood glucose levels has been elucidated, i.e., by pancreatic $\beta$-cell regeneration, insulin secretion stimulation, antioxidant enzyme restoration, glucose uptake enhancement, metabolic enzyme regulation, lipid profile amelioration, and digestive enzyme inhibition. The combination of the $C$. grandis extract with other plant extracts and antidiabetic drugs showed a synergistic effect that is beneficial for increasing efficacy and safety.

\section{ACKNOWLEDGMENTS}

The authors gratefully acknowledge Universitas Gadjah Mada through the Rekognisi Tugas Akhir Tahun 2021 program, Grant No. 3190/UN1/DITLIT/DIT-LIT/PT/2021, for financial support.

\section{AUTHORS' CONTRIBUTIONS}

I Made Wisnu Adhi Putra initiated and drafted the review article. Nanang Fakhrudin, Arief Nurrochmad, and Subagus Wahyuono conducted revisions and reviews on the initial draft prior to submission to the journal website

\section{CONFLICT OF INTEREST}

All authors declare no conflicts of interest.

\section{ETHICAL APPROVAL}

This article does not contain any studies with human participants or animals performed by any of the authors.

\section{LIST OF ABBREVIATIONS}

ALP: Alkaline phosphatase; AMPK: 5' adenosine monophosphate-activated protein kinase; AST: Aspartate amino transferase; b.w.: Body weight; CAT: Catalase; CI: Combination index; 2-DG: 2-Deoxyglucose; DPPH:1,1-Diphenyl-2picrylhydrazyl; FFA: Free fatty acid; G6PDH: Glucose-6phosphate dehydrogenase; GLUT1: Glucose transporter 1; GLUT2: Glucose transporter 2; GLUT4: Glucose transporter 4; GH: Growth hormone; GSH: Reduced glutathione or Glutathione with sulfhydryl group; GPx: Glutathione peroxidase; GR: Glutathione reductase; GST: Glutathione S-transferase; HDL: High-density lipoprotein; HFD: High-fat diet; IC50: The half maximal inhibitory concentration; IF: Inhibitory factors; i.p.: Intraperitoneal; LDL: Low-density lipoprotein; MDA: Malondialdehyde; mRNA: Messenger ribonucleic acid; ROS: Reactive oxygen species; SGPT: Serum glutamic pyruvic transaminase; SGOT: Serum glutamic oxaloacetic transaminase; SOD: Superoxide dismutase; STZ: Streptozotocin; TC: Total cholesterol; TBARS: Thiobarbituric acid-reactive substances; TG: Triacylglycerol; VLDL: Very low-density lipoprotein.

\section{REFERENCES}

Adewole SO, Caxton-Martins EA, Ojewole JA. Protective effect of quercetin on the morphology of pancreatic $\beta$-cells of streptozotocin-treated diabetic rats. Afr J Tradit Complement Altern Med, 2007; 4(1):64-74.

Alagar RM, Sushma K, Banji D, Rao KNV, Selvakumar D. Evaluation of standardisation parameters, pharmacognostic study, preliminary phytochemical screening and in vitro antidiabetic activity of Coccinia indica fruits as per WHO guidelines. Indian J Pharm Biol Res, 2014; 2(3):54-64.
Alam MdM, Meerza D, Naseem I. Protective effect of quercetin on hyperglycemia, oxidative stress and DNA damage in alloxan induced type 2 diabetic mice. Life Sci, 2014; 109(1):8-14.

AL-Ishaq RK, Abotaleb M, Kubatka P, Kajo K, Büsselberg D. Flavonoids and their anti-diabetic effects: cellular mechanisms and effects to improve blood sugar levels. Biomolecules, 2019; 9:430-65.

Al-Madhagy SA, Mostafa NM, Youssef FS, Awad GEA, Eldahshan OA, Singab ANB. Metabolic profiling of a polyphenolic-rich fraction of Coccinia grandis leaves using LC-ESI-MS/MS and in vivo validation of its antimicrobial and wound healing activities. Food Funct, 2019; 10(10):6267-75.

Alsahli M, Gerich JE. Abnormalities of insulin secretion and $\beta$-cell defects in type 2 diabetes. In: Holt R, Cockram C, Flyvbjerg A, Goldstein B (eds.). Textbook of diabetes. 4th edition, Blackwell Publishing, Oxford, UK, pp 160-73, 2010

American Diabetes Association. Diagnosis and classification of diabetes mellitus. Diabetes Care, 2009; 32(Supplement 1):S62-7.

Andersen SE, Christensen M. Hypoglycaemia when adding sulphonylurea to metformin: a systematic review and network metaanalysis. Br J Clin Pharmacol, 2016; 82(5):1291-302.

Arumugam G, Manjula P, Paari N. A review: anti diabetic medicinal plants used for diabetes mellitus. J Acute Dis, 2013; 2(3):196-200.

Asmat U, Abad K, Ismail K. Diabetes mellitus and oxidative stress - a concise review. Saudi Pharm J, 2016; 24(5):547-53.

Attanayake AP, Jayatilaka KAPW, Mudduwa LKB. Antidiabetic potential of ivy gourd (Coccinia grandis, family: Cucurbitaceae) grown in Sri Lanka: a review. J Pharmacogn Phytochem, 2016; 5(6):286-9.

Attanayake AP, Jayatilaka KAPW, Mudduwa LKB, Pathirana C. Biochemical and histological evaluation of three selected medicinal plant extracts of Sri Lankan origin on dyslipidemia and oxidative stress in alloxan induced diabetic rats. J Bot, 2018; 2018:1-8.

Attanayake AP, Jayatilaka KAPW, Mudduwa LKB, Pathirana C. $\beta$-cell regenerative potential of selected herbal extracts in alloxan induced diabetic rats. Curr Drug Discov Technol, 2019; 16(3):278-84.

Attanayake AP, Jayatilaka KAPW, Pathirana C, Mudduwa LKB Antihyperglycemic activity of Coccinia grandis (L.) Voigt in streptozotocin induced diabetic rats. Indian J Tradit Knowl, 2015; 14(3):376-81.

Attanayake AP, Jayatilaka KAPW, Pathirana C, Mudduwa LKB. Efficacy and toxicological evaluation of Coccinia grandis (Cucurbitaceae) extract in male wistar rats. Asian Pac J Trop Dis, 2013; 3(6):460-6.

Balaraman AK, Singh J, Dash S, Maity TK. Antihyperglycemic and hypolipidemic effects of Melothria maderaspatana and Coccinia indica in streptozotocin induced diabetes in rats. Saudi Pharm J, 2010; 18(3):173-8.

Banerjee DD. Textbook of homoeopathic pharmacy. B Jain Publishers, New Delhi, India, 2002.

Bansal AK, Bilaspuri GS. Impacts of oxidative stress and antioxidants on semen functions. Vet Med Int, 2011; 2011:1-7.

Basavarajappa GM, Nanjundan PK, Alabdulsalam A, Asif AH, Shekharappa HT, Anwer MdK, Nagaraja S. Improved renoprotection in diabetes with combination therapy of Coccinia indica leaf extract and lowdose pioglitazone. Separations, 2020; 7(4):58-74.

Basu S, Yoffe P, Hills N, Lustig RH. The relationship of sugar to population-level diabetes prevalence: an econometric analysis of repeated cross-sectional data. PLoS One, 2013; 8(2):1-8.

Bell DSH. Combine and conquer: advantages and disadvantages of fixed-dose combination therapy. Diabetes Obes Metab, 2013; 15(4):291-300.

Bhat BM, Raghuveer CV, D’Souza V, Manjrekar PA. Antidiabetic and hypolipidemic effect of Salacia oblonga in streptozotocin induced diabetic rats. J Clin Diagn Res, 2012; 6(10):1685-7.

Chou TC, Talalay P. Quantitative analysis of dose-effect relationships: the combined effects of multiple drugs or enzyme inhibitors Adv Enzyme Regul, 1984; 22:27-55. 
Chou TC. Theoretical basis, experimental design, and computerized simulation of synergism and antagonism in drug combination studies. Pharmacol Rev, 2006; 58(3):621-81.

Da Silva Xavier G. The cells of the islets of Langerhans. J Clin Med, 2018; 7(3):54-71.

Deokate UA, Khadabadi SS. Pharmacology and phytochemistry of Coccinia indica. J Pharmacogn Phytother, 2011; 3(11):155-9.

Ediriweera ERHSS, Ratnasooriya WD. A review on herbs used in treatment of diabetes mellitus by Sri Lankan ayurvedic and traditional physicians. Ayu, 2009; 30(4):373-91.

Eid HM, Martineau LC, Saleem A, Muhammad A, Vallerand D, Benhaddou-Andaloussi A, Nistor L, Afshar A, Arnason JT, Haddad PS. Stimulation of AMP-activated protein kinase and enhancement of basal glucose uptake in muscle cells by quercetin and quercetin glycosides, active principles of the antidiabetic medicinal plant Vaccinium vitis-idaea. Mol Nutr Food Res, 2010; 54(7):991-1003.

Eid H, Nachar A, Thong F, Sweeney G, Haddad P. The molecular basis of the antidiabetic action of quercetin in cultured skeletal muscle cells and hepatocytes. Pharmacogn Mag, 2015; 11(41):74-81.

Ekor M. The growing use of herbal medicines: issues relating to adverse reactions and challenges in monitoring safety. Front Pharmacol, 2014; 4:1-10.

Eliza J, Usha PTA. Interaction of Coccinia indica with glibenclamide in alloxan induced diabetic rats. Indian J Vet Res, 2011; 20(1):1-7.

Eshrat MH. Effect of Coccinia indica (L.) and Abroma augusta (L.) on glycemia, lipid profile and on indicators of end-organ damage in streptozotocin induced diabetic rats. Indian J Clin Biochem, 2003; 18(2):45-63.

Gasparin FRS, Salgueiro-Pagadigorria CL, Bracht L, IshiiIwamoto EL, Bracht A, Constantin J. Action of quercetin on glycogen catabolism in the rat liver. Xenobiotica, 2003; 33(6):587-602.

Gómez-Huelgas R, Gómez Peralta F, Rodríguez Mañas L, Formiga F, Puig Domingo M, Mediavilla Bravo JJ, Miranda C, Ena J. Treatment of type 2 diabetes mellitus in elderly patients. Rev Clínica Esp, 2018; 218(2):74-88.

Gunjan M, Jana GK, Jha AK, Mishra U. Pharmacognostic and antihyperglycemic study of Coccinia indica. Int J Phytomedicine, 2010; 2:36-40.

Gurukar MSA, Mahadevamma S, Chilkunda ND. Renoprotective effect of Coccinia indica fruits and leaves in experimentally induced diabetic rats. J Med Food, 2013; 16(9):839-46.

Halliwell B. The wanderings of a free radical. Free Radic Biol Med, 2009; 46(5):531-42.

2015; 54:1-166.

Holstein N. Monograph of Coccinia (Cucurbitaceae). PhytoKeys,

Hu FB. Globalization of diabetes: the role of diet, lifestyle, and genes. Diabetes Care, 2011; 34(6):1249-57.

IDF. IDF diabetes atlas. 9th édition, International Diabetes Federation, Brussels, Belgium, 2019.

Islam MA, Khan MRI, Hossain MS, Alam AK, Wahed MII, Rahman BM, Anisuzzaman AS, Shaheen S, Ahmed M. Antidiabetic and hypolipidemic effects of different fractions of Coccinia cordifolia L. on normal and streptozotocin-induced diabetic rats. Pak J Pharm Sci, 2011; 24(3):331-8.

Islam MS, Parvin S, Uddin MN, Mazid MA. Antidiabetic and antioxidant activities of decoctions of Coccinia grandis Linn. and Centella asiatica (L.) on alloxan-induced diabetic rats. Bangladesh Pharm J, 2014; 17(1):86-91.

Jamwal A, Kumar S. Screening of antidiabetic activity and toxicity studies of Cephalandra indica Naud. Int J Toxicol Pharmacol Res, 2016; 8(4):256-60.

Jaiboon V, Boonyanupahap J, Suwansri S, Ratanatraiwong P, Hansawasdi C. Alpha amylase inhibition and roasting time of local vegetables and herbs prepared for diabetes risk reduction chili paste. Asian J Food Agro-Ind, 2010; 3(1):1-12.
Jasmin, Jaitak V. A review on molecular mechanism of flavonoids as antidiabetic agents. Mini Rev Med Chem, 2019; 19(9):762-86.

Kancherla V, Elliott JL, Patel BB, Holland NW, Johnson TM, Khakharia A, Phillips LS, Oakley Jr GP, Vaughan CP. Long-term metformin therapy and monitoring for vitamin B12 deficiency among older veterans. J Am Geriatr Soc, 2017; 65(5):1061-6.

Karunamoorthi K, Jegajeevanram K, Vijayalakshmi J, Mengistie E. Traditional medicinal plants: a source of phytotherapeutic modality in resource-constrained health care settings. J Evid Based Complement Altern Med, 2013; 18(1):67-74.

Kaushik U, Aeri V, Showkat Rm, Ali M. Cucurbitane-type triterpenoids from the blood glucose-lowering extracts of Coccinia indica and Momordica balsamina fruits. Pharmacogn Mag, 2017; 13(49):115-21.

Kharroubi AT, Darwish HM. Diabetes mellitus: the epidemic of the century. World J Diabetes, 2015; 6(6):850-67.

Kishore L, Singh R. Ameliorative effect of Cephalandra indica homeopathic preparation in STZ induced diabetic nephropathy rats. J Ayurveda Integr Med, 2019; 10(4):255-61.

Kishore L, Singh R. Effects of different homeopathic potencies of Cephalendra indica in treatment of neuropathic pain in streptozotocin induced diabetes. Bull Fac Pharm Cairo Univ, 2017; 55(2):273-80.

Kohli S, Kumar PN. Combined effect of Coccinia indica leaf extract with acarbose in type II diabetes induced neuropathy in rats. J Innov Pharm Biol Sci, 2014; 1(2):77-87.

Kondhare D, Lade H. Phytochemical profile, aldose reductase inhibitory, and antioxidant activities of Indian traditional medicinal Coccinia grandis (L.) fruit extract. 3 Biotech, 2017; 7(6):378-88

Kumar GP, Sudheesh S, Vayalakshmi NR. Hypoglycaemic effect of Coccinia indica: mechanism of action. Planta Med, 1993; 59:330-2.

Kumar M, Alok S, Jain SK, Dixit VK. Macroscopial, anatomical and physico-chemical studies on fruits of Coccinia indica Wight \& Arn (Cucurbitaceae). Asian Pac J Trop Dis, 2014; 4(Suppl 1):121-8.

Kumar S, Kumar V, Prakash O. Enzymes inhibition and antidiabetic effect of isolated constituents from Dillenia indica. BioMed Res Int, 2013; 2013:1-7.

Kwon O, Eck P, Chen S, Corpe CP, Lee J, Kruhlak M, Levine M. Inhibition of the intestinal glucose transporter GLUT2 by flavonoids FASEB J, 2007; 21(2):366-77.

Limanto A, Simamora A, Santoso AW, Timotius KH. Antioxidant, $\alpha$-glucosidase inhibitory activity and molecular docking study of gallic acid, quercetin and rutin: a comparative study. Mol Cell Biomed Sci, 2019; 3(2):67-74.

Loke YK, Singh S, Furberg CD. Long-term use of thiazolidinediones and fractures in type 2 diabetes: a meta-analysis. Can Med Assoc J, 2009; 180(1):32-9.

Mallick C, Chatterjee K, Biswas MG, Ghosh D. Antihyperglycemic effects of separate and composite extract of root of Musa paradisiaca and leaf of Coccinia indica in streptozotocin-induced diabetic male albino rat. Afr J Tradit Complement Altern Med, 2007; 4(3):362-71.

Mallick C, De D, Ghosh D. Correction of protein metabolic disorders by composite extract of Musa paradisiaca and Coccinia indica in streptozotocin-induced diabetic albino rat: an approach through the pancreas. Pancreas, 2009; 38(3):322-9.

Manjula S, Ragavan B. Hypoglycemic and hypolipidemic effect of Coccinia indica Wight \& Arn in alloxan induced diabetic rats. Anc Sci Life, 2007; 27(2):34-7.

Mao ZM, Shen SM, Wan YG, Sun W, Chen HL, Huang MM, Yang JJ, Wu W, Tang HT, Tang RM. Huangkui capsule attenuates renal fibrosis in diabetic nephropathy rats through regulating oxidative stress and p38MAPK/Akt pathways, compared to $\alpha$-lipoic acid. J Ethnopharmacol, 2015; 173:256-65.

Meenatchi P, Purushothaman A, Maneemegalai S. Antioxidant, antiglycation and insulinotrophic properties of Coccinia grandis (L.) in vitro: possible role in prevention of diabetic complications. J Tradit Complement Med, 2017; 7(1):54-64. 
Modak M, Dixit P, Londhe J, Ghaskadbi S, Devasagayam TPA. Indian herbs and herbal drugs used for the treatment of diabetes. J Clin Biochem Nutr, 2007; 40:163-73.

Mohammed SI, Chopda MZ, Patil RH, Vishwakarma KS, Maheshwari VL. In vivo antidiabetic and antioxidant activities of Coccinia grandis leaf extract against streptozotocin induced diabetes in experimental rats. Asian Pac J Trop Dis, 2016; 6(4):298-304.

Monalisa MN, Al-Nahain A, Rahmatullah M. Coccinia grandis: a plant with multiple ethnomedicinal uses. World J Pharm Pharm Sci, 2014; 3(9):1382-94.

Mukherjee PK, Nema NK, Maity N, Sarkar BK. Phytochemical and therapeutic potential of cucumber. Fitoterapia, 2013; 84:227-36.

Mukhopadhyay P, Prajapati AK. Quercetin in anti-diabetic research and strategies for improved quercetin bioavailability using polymer-based carriers - a review. RSC Adv, 2015; 5(118):97547-62.

Nasirian F, Sarir H, Moradi-kor N. Antihyperglycemic and antihyperlipidemic activities of Nannochloropsis oculata microalgae in streptozotocin-induced diabetic rats. Biomol Concepts, 2019; 10:37-43.

Oguntibeju OO. Type 2 diabetes mellitus, oxidative stress. Int J Physiol Pathophysiol Pharmacol, 2019; 11(3):45-63.

Packirisamy M, Ayyakkannu P, Sivaprakasam M. Antidiabetic effect of Coccinia grandis (L.) Voigt (Cucurbitales: Cucurbitaceae) on streptozotocin induced diabetic rats and its role in regulating carbohydrate metabolizing enzymes. Braz J Biol Sci, 2018; 5(11):683-98.

Pal A, Misra BB, Das SS, Gauri SS, Patra M, Dey S. Antidiabetic effect of Cephalandra indica $\mathrm{Q}$ in diabetic rats. Indian J Res Homoeopathy, 2013; 7(2):81-90.

Patel AR, Ishnava KB. In vitro shoot multiplication from nodal explants of Coccinia grandis (L.) Voigt and it's antidiabetic and antioxidant activity. Asian J Biol Sci, 2015; 8(2):57-71.

Patra JC, Chua BH. Artificial neural network-based drug design for diabetes mellitus using flavonoids. J Comput Chem, 2011; 32(4):555-67.

Pekamwar SS, Kalyankar TM, Kokate SS. Pharmacological activities of Coccinia grandis: review. J Appl Pharm Sci, 2013; 3(5):114-9.

Prakash R, Kumar M, Singh DK, Chandra M, Verma D. Antidiabetic effect of Morinda citrofolia and Coccinia indica in alloxan induced diabetic rats. Adv Biores, 2010; 1(1):75-7.

Pulbutr P, Saweeram N, Ittisan T, Intrama H, Jaruchotik A, Cushnie B. In vitro $\alpha$-amylase and $\alpha$-glucosidase inhibitory activities of Coccinia grandis aqueous leaf and stem extracts. J Biol Sci, 2017; 17(2):61-8.

Purintrapiban J, Keawpradub N, Jansakul C. Role of the water extract from Coccinia indica stem on the stimulation of glucose transport in L8 myotubes. Songklanakarin J Sci Technol, 2006; 28(6):1199-208.

Putra IMWA, Ate OT, Kusumawati IGAW, Nursini NW. Water extracts from the combination of Coccinia grandis (L.) Voigt leaves and Averrhoa bilimbi L. fruits with antidiabetic properties: an in vitro study. Asian J Pharm Clin Res, 2020; 13(4):24-8.

Randhawa K, Kumar D, Jamwal A, Kumar S. Screening of antidepressant activity and estimation of quercetin from Coccinia indica using TLC densitometry. Pharm Biol, 2015; 53(12):1867-74.

Rasoanaivo P, Wright CW, Willcox ML, Gilbert B. Whole plant extracts versus single compounds for the treatment of malaria: synergy and positive interactions. Malar J, 2011; 10(S1):1-12.

Rastogi DP, Saxena AC, Kumar S. Pancreatic beta-cell regeneration: a novel anti-diabetic action of Cephalendra indica mother tincture. Br Homeopath J, 1988; 77(03):147-51.

Roy K, Saha S, Biswas S, Ahmed W, Mariappan G. In vivo assessment of antidiabetic and antioxidant activities of Blumea balsamifera in streptozotocin-diabetic rats. Res J Med Plants, 2013; 7(1):48-57.

Ruby S, Banurekha J, Loganathan J, Jaykar B. Investigation of phytochemical studies and evaluation of antidiabetic synergestic effect in the methanolic extracts of Coccinia grandis (L.) J. Voigt and Trigonella foenum-graecum (L.). Asian J Pharm Anal Med Chem, 2014; 2(3):183-5.
Sakharkar P, Chauhan B. Antibacterial, antioxidant and cell proliferative properties of Coccinia grandis fruits. Avicenna J Phytomed, 2017; 7(4):295-307.

Saklani A, Parcha V, Dhulia I, Kumar D. Combined effect of Coccinia indica (Wight \& Arn) and Salvadora oleoides (decne) on blood glucose level and other risk factors associated with type 2 diabetes mellitus in alloxan induced diabetic rats. Int J Pharm Pharm Sci, 2012; 4(4):79-84.

Sampath S, Narasimhan A, Chinta R, Nair KRJ, Khurana A, Nayak D, Kumar A, Karundevi B. Effect of homeopathic preparations of Syzygium jambolanum and Cephalandra indica on gastrocnemius muscle of high fat and high fructose-induced type-2 diabetic rats. Homeopathy, 2013; 102(3):160-71.

Scheepmaker MM, Gower NT. The quality of selected South African and international homoeopathic mother tinctures. Afr J Tradit Complement Altern Med, 2011; 8:46-52.

Seaquist ER, Miller ME, Fonseca V, Ismail-Beigi F, Launer LJ, Punthakee Z, Sood A. Effect of thiazolidinediones and insulin on cognitive outcomes in ACCORD-MIND. J Diabetes Complications, 2013; 27(5):485-91.

Sekar V, Mani S, Malarvizhi R, Nithya P, Vasanthi HR Antidiabetic effect of mangiferin in combination with oral hypoglycemic agents metformin and gliclazide. Phytomedicine, 2019; 59:152901.

Shakya VK. Antidiabetic activity of Coccinia indica in streptozotocin induced diabetic rats. Asian J Chem, 2008; 20(8):6479-82.

Shibib BA, Amin MA, Hasan AM, Rahman R, c. A creeper, Coccinia indica, has anti-hyperglycaemic and anti-ureogenic effects in diabetic rats. J Pak Med Assoc, 2012; 62(11):1145-8.

Shibib BA, Khan LA, Rahman R. Hypoglycaemic activity of Coccinia indica and Momordica charantia in diabetic rats: depression of the hepatic gluconeogenic enzymes glucose-6-phosphatase and fructose-1,6-bisphosphatase and elevation of both liver and red-cell shunt enzyme glucose-6-phosphate dehydrogenase. Biochem J, 1993; 292(1):267-70.

Sudha P, Zinjarde SS, Bhargava SY, Kumar AR. Potent $\alpha$-amylase inhibitory activity of Indian Ayurvedic medicinal plants. BMC Complement Altern Med, 2011; 11:5-15.

Sutradhar BK, Islam J, Shoyeb A, Khaleque HN, Sintaha M, Noor FA, Newaz W, Rahmatullah M. An evaluation of antihyperglycemic and antinociceptive effects of crude methanol extract of Coccinia grandis (L.) J Voigt. (Cucurbitaceae) leaves in swiss albino mice. Adv Nat Appl Sci, 2011; 5(1):1-5.

Sy SD, Nst MR, Novianty R. Analysis of ethanol extract and infusion of tamarind leaves, parasite herbs, mimosa herbs as antidiabetic. Appl Sci Technol, 2017; 1(1):592-6.

Tupe RS, Kulkarni A, Adeshara K, Shaikh S, Shah N, Jadhav A. Syzygium jambolanum and Cephalandra indica homeopathic preparations inhibit albumin glycation and protect erythrocytes: an in vitro study. Homeopathy, 2015; 104(3):197-204.

Venkateswaran S, Pari L. Effect of Coccinia indica on blood glucose, insulin and key hepatic enzymes in experimental diabetes. Pharm Biol, 2002; 40(3):165-70.

Viljoen A, Sinclair AJ. Diabetes and insulin resistance in older people. Med Clin North Am, 2011; 95(3):615-29.

Waisundara VY, Watawana MI, Jayawardena N. Costus speciosus and Coccinia grandis: traditional medicinal remedies for diabetes. South Afr J Bot, 2015; 98:1-5.

Wakte MS, Patil AD. A review on preclinical studies conducted with homeopathic medicine Cephalandra indica as an anti-hyperglycemic agent. Int J High Dilution Res, 2019; 18(3-4):35-46.

Wasantwisut E, Viriyapanich T. Ivy gourd (Coccinia grandis Voigt, Coccinia cordifolia, Coccinia indica) in human nutrition and traditional applications. In: Simopoulos AP, Gopalan C (eds.). Plants in human health and nutrition policy. KARGER, Basel, Switzerland, pp 60-6, 2003. 
Wong TS, Ismail HF, Hashim Z, Majid FAA. Synergistic antihyperglycaemic effect of combination therapy with gallic acid and andrographolide in streptozotocin-induced diabetic rats. Biocatal Agric Biotechnol, 2019; 18:1-5.

Yang DK, Kang HS. Anti-diabetic effect of cotreatment with quercetin and resveratrol in streptozotocin-induced diabetic rats. Biomol Ther, 2018; 26(2):130-8.
How to cite this article:

Putra IMWA, Fakhrudin N, Nurrochmad A, Wahyuono S. Antidiabetic activity of Coccinia grandis (L.) Voigt: Bioactive constituents, mechanisms of action, and synergistic effects. J Appl Pharm Sci, 2022; 12(01):041-054. 